JPdK Volume 2 No 2 Tahun 2020 Halaman 130-138

JURNAL PENDIDIKAN dan KONSELING

\title{
Konsep Nusyûz Menurut Hukum Islam Berkesetaraan Gender
}

\author{
Ahmad Nurwahid ${ }^{1}$, Teki Prasetyo Sulaksono ${ }^{2} \&$ Yuli Kurniasih $^{3}$ \\ UIN Raden Intan Lampung \\ Email: ahmadwahiid@gmail.com
}

\begin{abstract}
Abstrak
Penelitian ini bertujuan untuk menganalisis tentang konsep nusyûz, terutama ketika dihadapkan pada wacana gender. Kehidupan rumah tangga merupakan salah satu sisi yang terpenting dalam kehidupan setiap manusia. Pemahaman tentang nusyûz sebagai suatu problematika perkawinan dapat berkembang sesuai dengan kompleksitas yang dihadapi suami istri. Dalam pernikahan yang dipandang penting bagi setiap individu, untuk memperoleh legitimasi hukum dan sosial terhadap percampuran fisik dan non fisik dari dua jenis kelamin yang berbeda, sehingga memperoleh pengakuan, baik dari sudut pandang hukum, maupun sosial.
\end{abstract}

Bentuk nusyûz suami istri secara umum mengarah kepada pelanggaran kewajiban dan hak dalam perkawinan. Bentuk nusyûz istri seperti ketidak sediaan istri untuk menerima suami lahir dan batin, dan ketidak patuhan istri kepada suami dalam perkara yang tidak bertentangan dengan perintah agama. Ijtihad ulama terdahulu dalam masalah nusyûz tidak terlepas dari realitas sosial budaya suami istri. Ulama madzhab sepakat bahwa istri yang melakukan nusyûz tidak berhak atas nafkah, tetapi berbeda pendapat tentang batasan nusyûz yang mengakibatkan gugurnya hak nafkah. Perbedaan implikasi nusyûz antara suami istri dalam hukum Islam diletakkan dalam kerangka suami sebagai pemimpin keluarga yang memiliki tanggung jawab lebih besar dari istri, seperti mencukupi kebutuhan nafkah istri, dan menjaga istri dari tindakan yang bertentangan dengan ajaran agama.

Kata Kunci: konsep nusyûz, hukum islam, gender

\section{PENDAHULUAN}

Pernikahan adalah salah satu peristiwa hukum yang penting bagi setiap individu, untuk memperoleh legitimasi hukum dan sosial terhadap percampuran fisik dan non fisik dari dua jenis kelamin yang berbeda, sehingga memperoleh pengakuan, baik dari sudut pandang hukum, maupun sosial. Dari sudut pandang hukum, sahnya perkawinan berdampak pada pengakuan negara terhadap lembaga perkawinan yang dilangsungkan, dan implikasi hukumnya, seperti kewajiban memberi nafkah oleh suami, harta bersama, hak waris dan status anak. Pernikahan dalam Islam dipandang sebagai ibadah dan merupakan cara yang paling sesuai dengan martabat manusia dalam memenuhi kebutuhan biologisnya.
Pernikahan menjadi sebab penghalang keburukan syahwat dan merupakan suatu yang penting dalam agama bagi setiap orang yang tidak berada dalam kelemahan untuk menikah (As-Subki, 2010).

Nusyûz merupakan problematika yang ditandai adanya perilaku kurang menyenangkan, pelanggaran hak, dan pembangkangan baik yang dilakukan oleh suami maupun istri. Pelanggaran hak, dan tidak memenuhi kewajiban dapat dilakukan oleh suami atau istri. Oleh karena itu, nusyûz dapat dilakukan oleh suami atau istri. Salah satu kewajiban suami adalah memberi nafkah lahir dan batin kepada istri, sebaliknya istri mempunyai kewajiban taat dan patuh kepada suami dalam perkara yang tidak bertentangan dengan syari'at Islam. 
Pembangkangan istri terhadap kewajiban yang harus dilakukan kepada suami dalam hukum Islam disebut dengan nusyûz. Nusyûz bermakna kedurhakaan yang dilakukan oleh seorang istri terhadap suaminya. Hal ini bisa terjadi dalam bentuk pelanggaran perintah, penyelewengan dan hal-hal yang dapat mengganggu keharmonisan rumah tangga (Tarigan, 2004). Nusyûz secara etimologi berarti "membangkang" (Basyir,2009).Secara terminologi nusyûz berarti sikap tidak patuh dari salah seorang diantara suami-istri. Wahbah Az-Zuhaili (2011) menjelaskan nusyûz adalah meninggalkan kewajiban bersuami-istri. Dalam bahasa arab ditegaskan bahwa nusyûz dalam rumah tangga adalah sikap yang menunjukkan kebencian seorang suami kepada istrinya atau sebaliknya. Namun lazimnya nusyûz diartikan sebagai durhaka atau kedurhakaan (Dahlan, 2003).

Tafsir Jalalain karangan Imam Jalaluin Al-Mahalli dan Imam Jalaludin As-Suyuti mengartikan "nusyûz" sebagai sikap tidak acuh hingga berpisah ranjang darinya dan melalaikan pemberian nafkahnya, ada kalanya karena marah atau karena terpikat oleh wanita yang lebih cantik dari istrinya. Definisi di atas dapat dipahami bahwa sikap tidak peduli atau bahkan sampai pada tingkat tidak mematuhi, timbulnya kebencian, pembangkangan suami atau istri terhadap hak dan kewajibannya dalam rumah tangga dan terjadi pada salah satu pihak maka disebut dengan nusyûz. Nusyûz sangat berkaitan erat dengan hak dan kewajiban suami-istri dalam kehidupan rumah tangga. Yakni apabila suami atau istri tidak menjalankan kewajibankewajibannya maka suami atau istri tersebut dikatakan telah nusyûz. Semua hal tersebut tertuang dalam UU no 1 tahun 1974 tentang perkawinan

\section{METODOLOGI PENELITIAN}

Penelitian ini bersifat deskriptif kualitatif. Menurut Cresswel (2014) memberikan gambaran mengenai pendekatan kualitatif yang menciptakan atau secara induktif mengembangkan teori kontruktivisme sosial. Selanjutnya Bogdan dan Tailor (dalam Moleong, 2002) penelitian kualitatif adalah penelitian yang menghasilkan data deskriptif berupa katakata tertulis atau lisan dari oang atau perilaku yang diamati. Jika dihubungkan dengan penelitian ini, peneliti berusaha mendeskripsikan kondisi, pendapat yang sedang tumbuh, proses yang sedang berlangsung, akibat yang sedang terjadi atau kecenderungan yang tengah berkembang. Jika dihubungkan dengan penelitian ini, Permasalahan tentang nusyûz merupakan produk fiqh yang jika ditelusuri lebih mendalam merupakan hasil ijtihad ulama. Sebagai suatu hasil ijtihad, maka produk fiqh tersebut bersifat zhanni (dugaan) yang menyediakan ruang kritik, dan perbedaan pendapat, sesuai dengan metode ijtihad yang dipilih, dan dapat dianalisis keterkaitannya dengan realitas sosial dan budaya yang berkembang di tengah kehidupan para mujtahid.

\section{HASIL PENELITIAN DAN PEMBAHASAN}

\section{A. Nusyûz}

1. Pengetian Nusyûz

Pengertian nusyûz secara bahasa mengandung beberapa pengertian. Menurut Kamal (2009),Nusyûz maknanya adalah tempat yang tinggi." Menurut Ibnu Katsir dalam Ghoffar (2004), "An- Nusyûz adalah merasa lebih tinggi. Berarti istri yang merasa lebih tinggi di atas suaminya dengan meninggalkan perintahnya dan membencinya."

Al-Qurthubi (2006) menjelaskan pengertian Nusyûz secara bahasa :

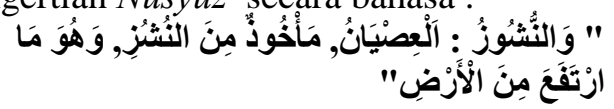

(Nusyûz berarti durhaka, diambil dari kata yang berarti tempat yang tinggi dari bumi)."

Adapun pengertian nusyûz menurut istilah dapat diartikan pengertian suatu kondisi yang tidak menyenangkan yang timbul dari istri maupun suami, sekalipun kuantitasnya lebih sering ditimbulkan dari 
pihak istri (Ghanim, 2006). Dalam pengertian lain disebutkan nusyûz adalah sebuah sikap mengingkari tugas dan kewajiban rumah tangga yang kerap kali menimbulkan runtuhnya bangunan sebuah rumah tangga (Ghanaim, 2009).

Pengertian di atas, lebih menekankan pengertian nusyûz secara umum, yang berarti bahwa pengertian nusyûz dapat

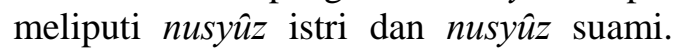
Namun demikian terdapat beberapa pendapat yang lebih menekankan nusyûz sebagai ketidak patuhan istri dalam menjalankan kewajiban rumah tangga.

Menurut Abu Malik Kamal, nusyûz diartikan pembangkangan seorang istri kepada suami di dalam sesuatu yang diwajibkan oleh Allah Swt kepada istri berupa ketaatan kepada suami, seakan istri merasa lebih tinggi dan menyombongkan diri kepadanya.

Menurut Mahmud Al-Misry (2006), pengertian nusyûz secara istilah diartikan sebagai kedurhakaan wanita (istri) terhadap suaminya dalam perkara yang diwajibkan Allah kepada istri untuk taat kepada suami, seakan istri tersebut merasa lebih tinggi danmengungguli suaminya).

Mengacu pengertian di atas, dapat diambil pengertian bahwa nusyûz adalah ketidak patuhan istri terhadap suami dalam perkara yang tidak bertentangan dengan hukum Allah tanpa alasan yang sah. Berdasarkan perspektif tersebut, maka suami mempunyai hak untuk ditaati oleh istri selama dalam hal yang dibenarkan oleh agama, pembangkangan istri terhadap suami dalam hal ini disebut dengan nusyûz.

Nusyûz didefinisikan sebagai sebuah sikap ketika istri tidak bersedia melaksanakan kewajibannya yaitu kewajiban utama berbakti lahir dan batin kepada suami dan kewajiban lainnya adalah menyelenggarakan dan mengatur keperluan rumah tangga sehari-hari dengan sebaik-baiknya.

\section{Hukum Nusyûz}

Suami dalam perspektif Islam memiliki legitimasi untuk bertindak sebagai pemimpin rumah tangga. Kedudukan tersebut mengisyaratkan adanya tanggung jawab yang lebih besar oleh suami dalam mengatur rumah tangga, sekaligus mensyaratkan ketaatan istri kepada suami. Pengaturan tersebut mengarah kepada adanya tertib hukum dalam lingkungan keluarga, dengan pelaksanaan hak dan kewajiban yang dilakukan oleh masingmasing suami istri.

Kedudukan suami sebagai kepala rumah tangga memerlukan dukungan dari istri dengan ketaatan dan kepatuhan terhadap suami dalam perkara yang tidak bertentangan dengan hukum Allah. Dalam perspektif tersebut, istri tidak boleh membangkang (nusyûz), karena dapat menganggu tertib hukum dalam lingkungan keluarga, dan mencederai hak suami untuk dipatuhi sebagai pemimpin rumah tangga. Demikian pula suami harus melaksanakan kewajibannya sebagai kepala rumah tangga dan memperlakukan istrinya dengan perlakuan yang baik (muasyarah bil makruf).

Pembangkangan istri terhadap suami merupakan perilaku yang mencederai hak suami sebagai kepala rumah tangga. Dalam Tafsir Ibnu Katsir (2006) Allah telah mewajibkan hak suami atas istri, dengan ketaatan istri kepada suami, serta mengharamkan maksiat kepada suami,karena keutamaan dan kelebihan yang dimiliki suami atas istri.

Berdasarkan pendapat di atas, dapat dipahami bahwa nusyûznya istri dalam hukum Islam dipandang sebagai perbuatan yang melanggar ha-hak suami sebagaimana dijelaskan dalam hadits riwayat Imam Muslim sebagai berikut :

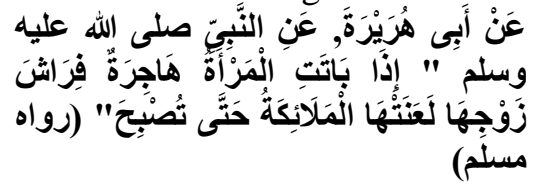

"Dari Abu Hurairah dari Nabi Saw, ia bersabda apabila seorang istri semalaman meninggalkan tempat tidur suaminya, maka malaikat melaknatinya sampai masuk waktu pagi" (H.R. Muslim)

Berdasarkan hadits di atas, maka nusyûz adalah perbuatan yang diancam dengan kecaman yang keras dari Allah, sampai istri kembali memenuhi hak-hak suami atas dirinya. Ajaran Islam menekankan pentingnya keseimbangan antara hak dan kewajiban dalam rumah tangga. Oleh 
karena itu, kepatuhan istri harus diimbangi dengan perlakuan yang baik oleh suami kepada istri. Dalam hal ini, suami juga tidak diperbolehkan melakukan nusyûz kepada istri, sebagaimana tidak diperbolehkannya istri melakukan nusyûz kepada suami. Suami harus memperlakukan istrinya dengan perlakuan yang baik (muasyaroh bil makruf) sebagaimana disebutkan dalam ayat sebagai berikut :

"Dan bergaulah dengan mereka secara patut. Kemudian bila kamu tidak menyukai mereka, (maka bersabarlah) karena mungkin kamu tidak menyukai sesuatu, padahal Allah menjadikan padanya kebaikan yang banyak." (Q.S. anNisa' : 19).

Dalam ayat di atas, Allah ingin mengingatkan kepada suami agar bergaul secara ma'ruf dengan istri. Kebencian suami terhadap perilaku yang mungkin dilakukan istri, tidak seharusnya mendorong suami mengabaikan hak-hak istri. Sebab mungkin saja suami membenci sesuatu yang di dalamnya terkandung kebaikan. Ayat di atas mengandung pesan pentingnya sikap objektif dalam menilai orang lain, khususnya terhadap istri yang sehari-hari bergaul bersama suami. Penilaian suami terhadap kekurangan istri hendaknya juga melihat kekurangan istri sebagai bagian dari tanggung jawab suami, sehingga suami memiliki kewajiban mendidik, dan meluruskan.

Hubungan baik sebagaimana dijelaskan di atas adalah hubungan antara suami istri yang dilandasi oleh kasih sayang dan kelembutan. Makna yang terkandung dalam hubungan baik tersebut mencakup tidak melakukan perkara yang menyakitkan, tidak menunda pemenuhan hak istri pada saat suami mampu memenuhinya, dan tidak menampakkan rasa tidak senang pada saat memberikan haknya istri.

\section{Bentuk-bentuk Nusyûz \\ a. Nusyûz Suami}

Kemungkinan nusyûz tidak hanya datang dari istri akan tetapi dapat juga datang dari suami. Adapun contoh-contoh nusyûz suami terhadap istri antara lain adalah sikap tidak senang berdampingan dan selalu menjauhi, tidak menyapa dan tidak mau berbincang-bincang dan mengabaikan hak-hak istri (Utsman, 1990).

As-Sadlani sebagaimana dikutip oleh Z.A. Kadir (2006) mengemukakan bentukbentuk nusyûz yang dilakukan oleh suami dalam bentuk perkataan maupun perbuatan

1. Keangkuhan, kesewenangwenangan dan kesombongan sang suami kepada istrinya.

2. Sikap suami yang memusuhi istrinya baik dengan pukulan, cercaan maupun hinaan yang pada akhirnya memperburuk hubungan suami istri.

3. Tidak melaksanakan kewajibannya sebagai seorang suami seperti tidak memberikan nafkah dan lain-lain.

4. Merusak hubungan dengan sang isteri yaitu dengan memisahkan ranjang tempat tidur, memutuskan hubungan komunikasi dan lain sebagainya.

Mengacu pendapat di atas, nusyûz yang dilakukan suami dapat terjadi dalam beberapa bentuk,seperti keangkuhan, kesombongan suami terhadap istrinya,tidak melaksanakan kewajiban yang harus dilakukan, dan tidak menjalankan komunikasi secara baik kepada istri. Secara umum tindakan nusyûz yang dilakukan suami kepada istrinya mengarah kepada tindakan yang merusak muasyarah bil ma'ruf (hubungan yang baik) sebagai dasar terbentuknya keluarga sakinah, mawaddah, wa rahmah. Jika istri melihat tanda-tanda nusyûz dari suaminya, maka dia dapat mengadakan sulh (perdamaian) dengan suaminya. Ibnu Katsir dalam hal ini mengatakan

Jika istri khawatir terhadap nusyûz suaminya, atau suami berpaling darinya, maka bagi istri boleh menggugurkan sebagian haknya dari nafkah, atau pakaian, atau tempat tinggal atau yang lainnya. Dan bagi suami boleh menerima hal itu dan tidak mengapa istri menyerahkannya kepada suami dan suami menerimanya. 
Memahami kutipan di atas, jika istri merasa khawatir terhadap nusyûz suaminya, atau ia melihat tanda-tanda nusyûz dari suami, maka ia dapat mengajukan sulh (perdamaian) dengan suami, dengan cara menggugurkan sebagian hak yang seharusnya ia terima dari suami.

\section{b. Nusyûz Istri}

Nusyûz yang dilakukan istri merupakan perbuatan yang mengindikasikan ketidak patuhan istri terhadap suami dalam perkara yang tidak bertentangan dengan perintah Allah Swt. Terciptanya kebahagiaan dan ketentraman berumah tangga tergantung pada komitmen suami-istri dalam melaksanakan peran dan kewajiban masing-masing. Jika peran dan kewajiban mereka telah dilakukan dengan baik, maka kehidupan perkawinan akan berjalan sesuai dengan apa yang mereka harapkan.

Abdur Rahman Al-Jazairi (2003) mengatakan "bagi nusyûz terdapat beberapa bentuk, misalnya : istri mencegah suami agar dapat mengambil kesenangan atas dirinya, baik memegang, mencium atau hubungan suami istri."

Sahrani (2013) Nusyûz yang dilakukan istri dapat pula terjadi dalam beberapa bentuk sebagai berikut :

1) Istri tidak mau pindah mengikuti suami untuk menempati rumah yang telah disediakan sesuai dengan kemampuan suami, atau istri meninggalkan rumah tangga tanpa izin suami.

2) Apabila keduanya tinggal di rumah istri atas seizin istri, kemudian pada suatu ketika istri melarang suami untuk masuk ke rumahnya, dan bukan karena hendak pindah rumah yang disediakan suami.

3) Istri menolak ajakan suaminya untuk menetap di rumah yang disediakannya tanpa alasan yang pantas.

4) Apabila istri bepergian tanpa suami atau mahramnya walaupun perjalanan itu wajib, seperti haji,karena perjalanan perempuan tidak dengan suami atau mahramnya termasuk maksiat.

Memahami pendapat di atas, bentuk nusyûz istri merupakan tindakan yang menunjukkan ketidak patuhan istri terhadap kepemimpinan suami, dengan segala kewenangannya yang mendapat pengakuan syara'. Kepemimpinan merupakan komponen yang harus ada dalam komunitas sosial manapun, termasuk dalam keluarga. Kepemimpinan akan efektif apabila mendapat dukungan dari anggotanya. Dalam perspektif ini, kepatuhan istri menjadi syarat mutlak tercapainya efektifitas kepemimpinan yang dilakukan suami dalam mewujudkan keluarga yang sakinah, mawaddah wa rahmah.

Lebih lanjut tentang bentuk-bentuk nusyûznya istri sebagai mana dijelaskan oleh Al Bukho (1992) Nusyûznya seorang istri adalah tindakannya yang keluar dari ketaatan terhadap suaminya dean mendurhakainya, seperti keluar dari rumah suami tanpa udzur dan tanpa izin dari suaminya, atau pergi tanpa mendapat izin dan ridho dari suaminya, atau tidak membukakan pintu agar suaminya dapat masuk rumah, atau tidak memungkinkan suaminya dapat menjamah dirinya tanpa ada udzur seperti sakit, atau ketika suami mengundangnya tetapi istri justru sibuk dengan keperluannya sendiri.

\section{Sebab-sebab Terjadinya Nusyûz}

Nusyûz merupakan problematika rumah tangga yang dapat disebabkan oleh pihak istri, suami atau pihak dari keluarga suami dan istri. Timbulnya nusyûz baik dari istri maupun suami menggambarkan adanya kurangnya kemampuan dalam mengatasi masalah yang timbul dalam perkawinan, baik yang berkaitan dengan masalah mental, ekonomi, maupun hubungan sosial di antara keluarga suami istri.

Penyebab terjadinya nusyûz dapat berasal dari istri atau teman-temannya, suami atau sahabatnya, wali istri dan kerabatnya, dan faktor lainnya. Selanjutnya Menurut Huzaimah Tahido Yango (2005) problematika rumah tangga yang dapat menyebabkan terjadinya nusyûz dan perselisihan suami istri adalah sebagai berikut :

a. Dominasi yang tidak seimbang, apabila suatu keluarga didominasi oleh kekuasaan salah satu pihak, misalnya yang bersifat otoriter dari suami atau dominasi seorang istri, maka konflik pasti akan terjadi. 
b. Kendali orang tua yang berlebihan.

c. Ketidak mampuan memberikan kepuasan pada salah satu pihak atau keduanya, dapat diakibatkan oleh kurangnya pengetahuan, perasaan malu dan sebagainya.

d. Perbedaan status sosial, hobi, faham, keyakinan, dan agama. Hal ini akan menimbulkan konflik dalam menentukan pilihan bahkan mengasuh dan mendidik anak, sampai pada yang sepele.

e. Latar kehidupan masa lalu yang kurang baik.

f. Masalah ekonomi. Kesejahteraan keluarga sangat diperlukan dalam membina rumah tangga. Keadaan ekonomi yang sulit serta tidak diterima dengan kesabaran akan membawa rumah tangga ke situasi yang kurang bahagia.

Memahami kutipan di atas, dapat dikemukakan bahwa penyebab terjadinya nusyûz cukup kompleks, baik dikarenakan faktor psikologis, watak dan mental salah satu pihak suami istri, campur tangan orang tua, perbedaan hobi, faham, keyakinan, dan masalah ekonomi. Nusyûz dapat dapat pula terjadi karena akumulasi dari beberapa faktor di atas, seperti faktor kurangnya pengertian ditambah faktor ekonomi, atau faktor campur tangan keluarga ditambah faktor kepribadian dari suami istri.

\section{a. Sebab Nusyûz dari Istri}

Dinamika sosial dewasa ini membuka peluang kepada istri untuk tidak sekedar menjadi ibu rumah tangga. Istri dapat menempuh karier di luar rumah dengan berbagai macam profesi yang menuntut tanggung jawab, waktu, tenaga dan fikiran, sehingga mengurangi keberadaannya di rumah.

Di sisi lain masyarakat juga semakin menyadari potensi peran wanita dalam berbagai sektor publik, seperti pendidikan, layanan kesehatan dan perbankan. Kondisi ini semakin memberi kesempatan kepada istri untuk memperoleh penghasilan sendiri tanpa harus bergantung kepada pemberian suami.
Terjadinya pergeseran pandangan yang tidak mempermasalahkan peran wanita di luar rumah mendorong peran yang lebih luas dari peran sebagai ibu rumah tangga menjadi figur yang ikut berkontribusi dalam kemajuan publik. Hal ini menegaskan perubahan pandangan masyarakat yang tidak mempermasalahkan isu gender dalam berbagai sektor kehidupan.

Nusyûz dapat tercermin dari ketidak mampuan istri menanggung kehidupan rumah tangga dan ketidak tahuannya akan hak dan kewajiban yang telah ditentukan oleh hukum agama. Aktifitas istri di luar tidak menimbulkan masalah dalam rumah tangga sepanjang dirinya tidak melupakan tugas utama dan kewajibannya dalam keluarga. Dalam hal ini, timbulnya nusyûz dari istri dapat diakibatkan karena kelalaian istri dalam menjalankan tugasnya atau dikarenakan faktor pergaulan di luar rumah yang dapat mendorong pada ketidak harmonisan hubungan suami istri.

\section{b. Sebab Nusyûz dari Suami}

Penyebab timbulnya nusyûz selain berasal dari istri, juga dapat berasal dari suami. Kondisi psikologis suami dengan tuntutan tanggung jawab yang besar dapat memicu tindakan sewenang-wenang suami.Nusyûz juga bisa dilakukan oleh suami. Biasanya hal itu terjadi akibat dia suka bergaul dengan teman-teman yang jahat, atau karena dia tertekan oleh situasi sosial yang sulit sehingga secara psikis dia terpaksa lari dari tanggung jawabnya. Akibatnya dia melakukan perlawanan terhadap istri dan berpaling darinya. Semua aktifitasnya didominasi kebencian dan akhlak yang buruk, mengabaikan hak istri, enggan memperlakukannya dengan baik, suka berkata kasar kepadanya, dan gemar menyakitinya.

Memahami kutipan di atas, nusyûz sebagai pelanggaran terhadap hak dan kewajiban dalam rumah tangga merupakan problematika yang tidak berdiri sendiri, melainkan dipengaruhi faktor internal dari diri suami, dan faktor eksternal. Nusyûz dari suami adalah bersikap keras terhadap istrinya, tidak mau menggaulinya dan tidak mau memberikan haknya. Biasanya 
nusyûz suami ini terjadi apabila tuntutan istri terlalu tinggi terhadap sesuatu yang di luar jangkauan (kemampuan) suami. Dengan demikian, solusinya yang tepat adalah bahwa istri harus mengurangi dan menyederhanakan tuntutan terhadap suaminya, jika memang ia menghendaki keutuhan dan keharmonisan rumah tangganya. Apabila istri memilih cerai dari pada bersikap seperti di atas, berarti ia telah melakukan kesalahan dalam rumah tangga serta menyebabkan runtuhnya mahligai perkawinan.

\section{B. Implikasi Nusyûz Istri}

Pemahaman tentang nusyûz sebagai suatu problematika perkawinan dapat berkembang sesuai dengan kompleksitas yang dihadapi suami istri. Dewasa ini tuntutan terhadap peran aktif perempuan semakin kuat, khususnya di sektor publik yang tidak membutuhkan kemampuan fisik. Muncul pula tuntutan tentang kesetaraan gender yang menekankan persamaaan hak suami dan istri. Diskursus yang penting untuk diketengahkan adalah sejauh mana implikasi nusyûz dapat dipandang memenuhi prinsip kesetaraaan dalam gender, sehingga menghilangkan anggapan bahwa hukum Islam bertindak deskriminatif terhadap istri.

\section{1) Hilangnya Hak Nafkah}

Ulama' madzhab sepakat bahwa istri yang melakukan nusyûz tidak berhak atas nafkah, tetapi berbeda pendapat tentang batasan nusyûz yang mengakibatkan gugurnya hak nafkah. Menurut madzhab Hanafi ketika istri berdiam diri di rumah suaminya, dan tidak keluar darirumah tanpa izin suaminya, maka dia masih disebut patuh, sekalipun dia tidak bersedia dicampuri tanpa dasar syara' yang benar. Penolakannya istri tersebut sekalipun haram tetapi tidak menggugurkan hak atas nafkah (Mughniyah, 2012).

\section{2) Pemukulan Yang Bersifat}

\section{Mendidik}

Munculnya wacana gender dalam permasalah fiqh tidak terlepas dari masuknya nilai-nilai hak asasi manusia yang dianggap sejalan dengan prinsip ajaran Islam dalam hal persamaan hak dan
keadilan.Gender dipahami sebagai atribut yang dilekatkan, dikodifikasi dan dilembagakan secara sosial, maupun kultural kepada perempuan dan laki-laki yang berkaitan dengan pikiran dan harapan masyarakat tentang bagaimana sebenarnya menjadi laki-laki dan perempuan. Dengan demikian gender adalah kontruksi sosial dan konsep kultural masyarakat, dapat berubah dari satu waktu ke waktu lain, berbeda dari satu masyarakat ke masyarakat lain, dan dari kelas tertentu ke kelas lain (Sulaiman, 2014).

Menurut Kamal (2009) mengatakan pemukulan terhadap istri yang nusyûz dibatasi dengan ketentuan sebagai berikut :

a. Hendaklah pukulan tidak melukai/menyakiti, seperti pukulan yang bisa mematahkan tulang atau merusak daging.

b. Tidak memukul lebih dari sepuluh kali.

c. Tidak memukul wajah dan tidak memukul bagian-bagian yang mematikan.

d. Dia harus meyakini bahwa pukulannya itu bisa menjadikan istrinya jera, karena sesungguhnya pukulan tersebut hanya sekedar wasilah (media) untuk memperbaiki. Sementara wasilah tidak disyariatkan ketika tidak ada keyakinan bahwa tujuanyang diharapkan akan terwujud. Jika tidak ada keyakinan demikian, hendaknya suami tidak memukulnya.

e. Menghentikan pukulan ketika istri telah mentaaatinya.

\section{Implikasi Nusyûz Suami}

Problematika perkawinan selain dapat berasal dari nusyûz istri, juga dapat berasal dari nusyûz suami. Sebagaimana dalam nusyûz istri terdapat solusi yang dapat dilakukan suami, maka dalam nusyûz suami istri dapat melakukan langkahlangkah yang dianjurkan syara' dalam menangani masalah nusyûz suami, yaitu melalui cara sulh (mediasi) dengan perantara hakam (mediator). 


\section{1) Gugatan Cerai}

Hukum Islam mengakui keberadaaan perceraian sebagai peristiwa hukum yang berdampak pada putusnya tali perkawinan. Dalam hukum Islam, hak menjatuhkan talak ada di pihak suami, namun istri juga diberi hak untuk mengajukan gugatan cerai ke pengadilan. Perceraian dipandang sebagai solusi terakhir, ketika tidak ditemukan lagi solusi lain, dan dengan pertimbangan apabila suami istri tetap dalam ikatan perkawinan, justru akan menimbulkan mafsadat yang lebih besar.

Menurut Wahbah Zuhaili (2011) gugatan dalam istilah fiqh adalah pengaduan kepada hakim tentang hak yang harus dipenuhi oleh orang lain. Dalam Kompilasi Hukum Islam, Pasal 132 ayat 1 disebutkan Gugatan perceraian diajukan oleh istri atau kuasanya pada Pengadilan Agama. Yang daerah hukumnya mewilayahi tempat tinggal penggugat kecuali istri meninggalkan tempat kediaman bersama tanpa izin suami.

\section{2) Khulu'}

Hukum Islam memberi jalan kepada istri yang menghendaki perceraian dengan mengajukan khulu', sebagaimana hukum Islam memberi jalan kepada suami untuk menceraikan istrinya dengan jalan talak. Jika dikaitkan dengan wacana gender, hukum Islam memberi bukti dengan adanya khulu' bahwa istri diberi kesempatan untuk keluar dari kesulitan rumah tangga yang dialaminya, dengan mengajukan permintaan cerai kepada suami.

\section{3) Gugatan Pidana}

Perselisihan suami istri, baik yang disebabkan oleh nusyûz nya istri, maupun nusyûz suami, hendaknya dapat diselesaikan dengan cara kekeluargaan, dengan harapan kedua suami istri dapat kembali menjalani kehidupan rumah tangga secara baik. Jika penyelesaian melalui kekeluargaan tidak berhasil, suami dapat menjatuhkan talak kepada istri, dan istri dapat mengajukan gugatan cerai atau khulu' kepada suami.

Suami atau istri merupakan subjek hukum yang kepadanya berlaku pertanggung jawaban, baik hukum perdata maupun hukum pidana. Ketika suami melanggar hak istri dalam masalah nafkah dan hubungan baik, maka bagi suami tersebut berlaku hukum perdata Islam yang kewenangannya berada pada hakim pengadilan agama.Menurut Syarifuddin (2003) Terminologi pidana dalam hukum Islam mengacu kepada al-ahkam aljinaiyyah, atau al-fiqhu al-jina'i, yaitu "hukum Islam yang secara khusus mengatur tentang pencegahan tidak kejahatan yang dilakukan manusia dan sanksi hukuman yang berkenaan dengan kejahatan itu."

\section{Rasionalisasi Perbedaan Implikasi Nusyûz antara Suami dan Istri}

Wacana gender memunculkan adanya anggapan bahwa hukum keluarga Islam tidak menempatkan istri pada kesetaraan yang sesuai dengan prinsip universal dewasa ini, seperti halnya poligami, perbedaan jumlah warisan yang diterima, dan pemukulan terhadap istri yang nusyûz. Anggapan tersebut menuntut adanya rasionalisasi atas perbedaan perlakuan antara suami istri. Mengingat perbedaan sumber dan acuan yang digunakan dalam hukum keluarga Islam, dan wacana gender, maka untuk mencari titik temu antara kedua perspektif tersebut, akan terasa sulit. Namun setidaknya diperlukan argumentasi rasional, yang mungkin dapat mendekatkan kedua perspektif tersebut berdasarkan nilai-nilai universal yang dapat diterima kedua pihak.

Salah satu pemahaman universal yang dapat ditawarkan untuk menjembati perbedaan perspektif antara hukum keluarga Islam dan wacana gender adalah aspek seksualitas (jenis kelamin) yang tidak dapat dirubah, ditukarkan, atau diganti. Sulaiman (2014) memberi penjelasan jenis kelamin tidak berubah, tidak dapat dipertukarkan, dan selalu sama, dimanapun dan kapan pun. Ia bersifat universal. Dengan demikian seks adalah pemberian Tuhan yang bersifat kodrati, universal, tidak berubah, dan tidak dapat dipertukarkan.

Implikasi dari perbedaan jenis kelamin (seks) adalah adanya reproduksi yang hanya dimiliki perempuan. Karakteristik 
dari perbedaan tersebut adalah menstruasi, mengandung dan melahirkan yang hanya dimiliki perempuan. Berdasarkan karakteristik tersebut, seorang yang diciptakan dengan jenis kelamin laki-laki tidak seharusnya menuntut untuk melahirkan, dan menyusui, karena bertentangan dengan fitrah, dan secara biologis tidak akan dapat diwujudkan. Demikian pula seorang yang diciptakan dengan jenis kelamin perempuan, tidak seharusnya menuntut untuk memiliki ciriciri fisik yang hanya dimiliki laki-laki.

Legitimasi kepemimpinan suami dalam keluarga Islam, mengandung arti bahwa untuk menjalankan tertib hukum keluarga diperlukan adanya kewenangan yang dimilikinya, karena dalam unit sosial manapun kepemimpinan tidak akan efektif, jika tidak ada kewenangan. Dalam hal ini, kewenangan yang dimiliki suami adalah tahapan-tahapan yang dianjurkan syara' dalam menghadapi istri yang nusyûz, yaitu menasehati, meninggalkan di tempat tidur, dan memukul yang tidak menyakiti. Kewenangan tersebut seharusnya tidak menjadi permasalahan, mengingat memukul istri dibatasi dengan aturan yang sangat ketat, dan dalam konteks ketika nusyûz yang dilakukan istri sudah parah, sehingga tidak dapat diselesaikan dengan cara memberi nasihat, dan meninggalkan di tempat tidur.

\section{SIMPULAN}

Pemahaman tentang nusyûz sebagai suatu problematika perkawinan dapat berkembang sesuai dengan kompleksitas yang dihadapi suami istri. Dalam pernikahan yang dipandang penting bagi setiap individu, untuk memperoleh legitimasi hukum dan sosial terhadap percampuran fisik dan non fisik dari dua jenis kelamin yang berbeda, sehingga memperoleh pengakuan, baik dari sudut pandang hukum, maupun sosial. Bentuk nusyûz suami istri secara umum mengarah kepada pelanggaran kewajiban dan hak dalam perkawinan. Bentuk nusyûz istri seperti ketidak sediaan istri untuk menerima suami lahir dan batin, dan ketidak patuhan istri kepada suami dalam perkara yang tidak bertentangan dengan perintah agama. Ijtihad ulama terdahulu dalam masalah nusyûz tidak terlepas dari realitas sosial budaya suami istri. Ulama madzhab sepakat bahwa istri yang melakukan nusyûz tidak berhak atas nafkah, tetapi berbeda pendapat tentang batasan nusyûz yang mengakibatkan gugurnya hak nafkah. Perbedaan implikasi nusyûz antara suami istri dalam hukum Islam diletakkan dalam kerangka suami sebagai pemimpin keluarga yang memiliki tanggung jawab lebih besar dari istri, seperti mencukupi kebutuhan nafkah istri, dan menjaga istri dari tindakan yang bertentangan dengan ajaran agama. Oleh karena itu, ketika istri melakukan nusyûz, hak istri terhadap nafkah menjadi hilang, dan suami berhak memukul dengan pukulan yang tidak menyakiti istri dalam artian memblokade kekuasaannya dengan menarik hak kepemimpinan di tangan perempuan. Sedangkan apabila suami nusyûz, maka istri dapat mengajukan khulu' atau gugatan cerai, untuk melepaskan diri dari ikatan perkawinan dengan suami yang tentunya bagi istri masih mempunyai hak dalam pembagian harta kekayaan suaminya sebagai ganti rugi talak.

\section{DAFTAR PUSTAKA}

Abdul Fida' Ismail Ibnu Katsir, Tafsir Ibn Katsir, Jilid 5, alih bahasa M. Abdu Ghoffar, dkk, (Bogor : Pustaka Imam Syafi' I, 2004), h. 299

Al-Bukho, Mustofa al-Khin dan Mustofa. al-Fiqhu Al-Manhaji alal Mazhab al-Imam

asy-Syafi'I, Juz 4, (Damaskus: Dar al-Qolam, 1992), h. 107

Al-Jazari, Abdur Rahman. Al-Fiqhu alalMadzahibil Arba'ah, Juz 4, (Beirut: Dar al- Kutub al-Ilmiyah, 2003), cet ke-2, h. 498

Al-Qurtubi, Abu Abdillah Muhammad. AlJami' li Ahkami Al-Quran, Juz 6, (Beirut : Risalah Publiser, 2006), h. 282

As-Subki,Ali Yusuf.Fiqih Keluarga, alih bahasa Nur Khozin, (Jakarta: Amzah, 2010), h. 23 
Az-Zuhaili, Wahbah. Fiqh Islam WaAdilatuhu, (Jakarta: Gema Insani, 2011), h. 102

Basyir, Ahmad Azhar. sebagaimana dikutip oleh : M. A. Tihami dan Sohari Sahrani, Fikih Munakahat, (Jakarta: Rajawali Pers, 2009), h. 189

Cresswell, JW. (2014). Penelitian Kualitatif dan Metode Riset. Yogyakarta : Pustaka Pelajar

Dahlan, Abdul Azis. Ensiklopedia Hukum Islam, (Jakarta: Ihtiar Baru Van Hoeve, 2003), h. 1353

Ghanim, Shaleh bin. Jika Suami Istri Berselisih, Mengatasinya Bagaimana ? (Nusyûz ), alih bahasa Syauqi Algandri, (Jakarta : Gema Insani Press, 2006), h. 29

Ghanaim, Adil Rasyad. A Good Personality, alih bahasa Dudung Ramdani, (Jakarta : Mizan Publika, 2009), h. 7

Ibnu Katsir, Tafsir Al-Qur'an Al-Azdim, Juz 2, alih bahasa Bahrun Abu Bakar, (Jakarta : Sinar Baru Algesindo, 2000),h. 299

Kadir, Z.A.Nusyûz Suami Isteri (Tinjauan Sosiologis: Studi Kasus Pada Kluarga Tani) Couple Nusyûz (Anevaluation sociologis: The case study at farmer family), Jurnal Agrisistem, Desember 2006, Vol 2 No. 2 h. 109

Kamal, Abu Malik. Ensiklopedi Fiqh Wanita (Fiqhus Sunnah li-Nisa'), alih bahasa Beni Sarbeni, (Bogor : Pustaka Ibnu Katsir, 2009), h. 368

Kementerian Agama RI, Al-Qur'an Dan Terjemahannya, (Jakarta: PT. AdhiAksaraAbadi , 2011 )

Mahmud Al-Misry, Az-Ziwaj al-Islami asSa'id, ( Kairo : Maktabah Shofa, 2006), h. 770

Moleong, L.J. (2002). Metodologi Penelitian Kualitatif. Bandung: Remaja Rosdakarya

Mughniyah, Muhammad Jawad. Fiqh Lima Madzhab, alih bahasa Maskur Ab dkk, (Jakarta: Penerbit Lentera, 2012), h. 402
Muslim ibn Al-Hajjaj Al-Qusyairi AnNisaburi, Shahih Muslim Juz 1, (Kairo, Dar al-Hadits, 1991), h. 1059

Muhammad Utsman Al-Khahasyt, Sulitnya berumah tangga: Upaya mengatasinya Menurut Al-Qur'an, Hadits dan Ilmu Pengetahuan, Alih Bahasa A. Aziz Salim

Basyarahil, (Jakarta: Gema Insan Press, 1990), h. 87

Syarifuddin,Amir.Garis-garis Besar Fiqh, (Jakarta: Kencana, 2003), h. 252

Sulaiman,Sofyan A.PdanZulkarnainKarnai. Fiqh Feminis, Menghadirkan Teks Tandingan, (Yogyakarta: Pustaka Pelajar, 2014), h. 1

Tafsir Jalalain karangan Imam Jalaludin AlMahalli dan Imam Jalaludin AsSuyuti, Penerjemah Bahrun Abu Bakar, Terjemahan Tafsir Jalalain berikut Asbabun Nuzul, Jilid I, Cet. ke-7, (Bandung: sinar Baru Algensindo, 2007), h. 420

Tarigan, Amiur Nuruddin dan Azhari Akmal. Hukum Perdata Islam Di Indonesia, Jakarta: Kencana, 2004), cet. ke-2, h.209

Tihamil dan Sohari Sahrani, Fikih Munakahat, Kajian Fikih Nikah Lengkap, (Jakarta: Raja Grafindo Persada, 2013), h. 186

Undang- undang Republik Indonesia Nomor 1 Tahun 1974 Tentang Perkawinan dan Kompilasi Hukum Islam, Bandung : Citra Umbaran, 2007, hlm. 335

Undang-Undang Nomor 1 tahun 1974 tentang Perkawinan,

Yango, Huzaimah Tahido. Masail Fiqhiyah, (Bandung: Angkasa, 2005), h. 163 